\title{
Zearalenone Biodegradation by the Combination of Probiotics with Cell-Free Extracts of Aspergillus oryzae and Its Mycotoxin-Alleviating Effect on Pig Production Performance
}

\author{
Chaoqi Liu ${ }^{1}$, Juan Chang ${ }^{1}$, Ping Wang ${ }^{1}$, Qingqiang Yin ${ }^{1, *}$, Weiwei Huang ${ }^{1}$, Xiaowei Dang ${ }^{2}$, \\ Fushan $\mathrm{Lu}^{3}$ and Tianzeng Gao ${ }^{4}$ \\ 1 College of Animal Science and Veterinary Medicine, Henan Agricultural University, Zhengzhou 450002, \\ China; liuchaoqi2018@stu.henau.edu.cn (C.L.); changjuan2000@henau.edu.cn (J.C.); \\ wangping@henau.edu.cn (P.W.); hww5501@stu.henau.edu.cn (W.H.) \\ 2 Henan Delin Biological Product Co. Ltd., Xinxiang 453000, China; hndlbio@hndlbio.com \\ 3 Henan Puai Feed Co. Ltd., Zhoukou 466000, China; lufushan@puaifeed.com \\ 4 Henan Guangan Biotechnology Co., Ltd., Zhengzhou 450001, China; gaotianzeng@groundgroup.com \\ * Correspondence: qqy1964@henau.edu.cn
}

Received: 6 September 2019; Accepted: 18 September 2019; Published: 20 September 2019

\begin{abstract}
In order to remove zearalenone (ZEA) detriment-Bacillus subtilis, Candida utilis, and cell-free extracts from Aspergillus oryzae were used to degrade ZEA in this study. The orthogonal experiment in vitro showed that the ZEA degradation rate was $92.27 \%(p<0.05)$ under the conditions that Candida utilis, Bacillus subtilis SP1, and Bacillus subtilis SP2 were mixed together at $0.5 \%, 1.0 \%$, and $1.0 \%$. When cell-free extracts from Aspergillus oryzae were combined with the above probiotics at a ratio of 2:1 to make mycotoxin-biodegradation preparation (MBP), the ZEA degradation rate reached $95.15 \%(p<0.05)$. In order to further investigate the MBP effect on relieving the negative impact of ZEA for pig production performance, 120 young pigs were randomly divided into 5 groups, with 3 replicates in each group and 8 pigs for each replicate. Group A was given the basal diet with $86.19 \mu \mathrm{g} / \mathrm{kg}$ ZEA; group B contained $300 \mu \mathrm{g} / \mathrm{kg}$ ZEA without MBP addition; and groups C, D, and E contained $300 \mu \mathrm{g} / \mathrm{kg}$ ZEA added with $0.05 \%, 0.10 \%$, and $0.15 \%$ MBP, respectively. The results showed that MBP addition was able to keep gut microbiota stable. ZEA concentrations in jejunal contents in groups $\mathrm{A}$ and $\mathrm{D}$ were $89.47 \%$ and $80.07 \%$ lower than that in group $\mathrm{B}(p<0.05)$, indicating that MBP was effective in ZEA biodegradation. In addition, MBP had no significant effect on pig growth, nutrient digestibility, and the relative mRNA abundance of estrogen receptor alpha $(E R \alpha)$ genes in ovaries and the uterus $(p>0.05)$.
\end{abstract}

Keywords: Zearalenone; biodegradation; probiotics; cell-free extracts of Aspergillus oryzae; pig production performance

Key Contribution: The combination of beneficial microbes and cell-free extracts from A. oryzae was prepared to degrade ZEA effectively in vitro. Its addition in pig diets could alleviate ZEA negative effect on pig production performances.

\section{Introduction}

Zearalenone (ZEA) is one of the nonsteroidal estrogenic mycotoxins produced by Fusarium species to cause reproduction disorders in female animals such as abortion, false estrus, and so on [1]. Some of ZEA derivatives competitively bind estrogen receptors in the uterus and ovaries for reducing the 
ability of estrogen to bind receptors [2,3]. Long-term exposure to low doses of ZEA could alter estrogen receptor beta genes and induce epigenetic modification to inhibit the development of the ovary [4]. However, the relative transactivation activity of ZEA for estrogen receptor alpha was higher than estrogen receptor beta [5]. In sorghum, maize, wheat, rice, barley, and other crops and their sideline products, ZEA can be detected in their natural state during storage, transportation, and processing [6]. It was reported that ZEA was present in $92 \%$ of maize, $88 \%$ of maize silage, and $97 \%$ of small grains samples with a range of $141.30-253.07 \mu \mathrm{g} / \mathrm{Kg}$ [7-9]. Another report showed that the incidences and maximal levels of ZEA in raw cereal grains were $46 \%$ and $3049 \mu \mathrm{g} / \mathrm{kg}$ respectively, according to the global occurrence data reported during the past 10 years [10]. Generally, pigs are more sensitive to ZEA than other animals. Therefore, it is necessary to take some methods to eliminate ZEA in the animal feeding process, especially for female pigs.

In order to reduce ZEA detriment, many countries and organizations in the world have limited the maximal ZEA contents in food, feed, and cereals. For example, Australia allows a maximal ZEA content of $50 \mu \mathrm{g} / \mathrm{Kg}$ in cereals. ZEA content in cereals and cereal products is not allowed to exceed $100 \mu \mathrm{g} / \mathrm{Kg}$ in Italy. The maximal ZEA content in vegetable oil and cereals is $200 \mu \mathrm{g} / \mathrm{Kg}$ in France [11]. The maximal ZEA content in swine diets is $250 \mu \mathrm{g} / \mathrm{Kg}$ in China and Europe. Even so, ZEA content often exceeds these thresholds because of the different environments and inadequate storage conditions.

In order to detoxify ZEA, some physical, chemical, and biological methods have been conducted [12-15]. Some reports have shown that ZEA biological degradation is more effective than other methods $[16,17]$. There were some reports about ZEA biodegradation by microorganisms including Saccharomyces cerevisiae [18], Bacillus subtilis (B. subtilis) ANSB01G [19], and Lactobacillus plantarum [20]. In this study, B. subtilis SP1, B. subtilis SP2, Candida utilis (C. utilis), and cell-free extracts of Aspergillus oryzae (A. oryzae) were selected and combined together to determine the effect on ZEA detoxification and pig production performance, which will supply a new feed additive for safe animal feeding and production.

\section{Results}

\subsection{The Probiotics for ZEA Degradation}

In order to obtain the optimal ratio of probiotics for ZEA degradation, an orthogonal design was used in this experiment. Table 1 indicates that the biggest ZEA degradation rate in the nine treatments was $92.27 \%(p<0.05)$ under the conditions that Candida utilis, Bacillus subtilis SP1, and Bacillus subtilis SP2 were mixed together at a ratio of $\mathrm{A}_{1} \mathrm{~B}_{2} \mathrm{C}_{2}$ (i.e., $0.5 \%, 1.0 \%$, and $1.0 \%$, respectively). The analysis showed that the optimal addition ratio of $C$. utilis, $B$. subtilis SP1, and B. subtilis SP2 was $\mathrm{A}_{1} \mathrm{~B}_{1} \mathrm{C}_{3}$ (i.e., $0.50 \%, 0.50 \%$, and $1.50 \%$ ). However, further ZEA degradation experiments indicated that $\mathrm{A}_{1} \mathrm{~B}_{2} \mathrm{C}_{2}$ was better than $\mathrm{A}_{1} \mathrm{~B}_{1} \mathrm{C}_{3}$. Table 2 indicated that that the constructed model was accurate and acceptable $(p<0.01)$. Among the three strains of microbes, $C$. utilis had a significant effect on the model for ZEA degradation $(p<0.01)$, followed by B. subtilis SP1 and B. subtilis SP2 $(p>0.05)$. 
Table 1. Zearalenone (ZEA) degradation rate by probiotics.

\begin{tabular}{|c|c|c|c|c|c|}
\hline Number & C. utilis (\%) A & B. subtilis SP1 (\%) B & B. subtilis SP2 (\%) C & ZEA Content $(\mu \mathrm{g} / \mathrm{L})$ & ZEA Degradation Rate (\%) \\
\hline 1 & 0.5 & 0.5 & 0.5 & $79.14 \pm 24.91 \mathrm{e}$ & $85.00 \pm 4.98 \mathrm{ab}$ \\
\hline 2 & 0.5 & 1 & 1 & $40.80 \pm 6.68 \mathrm{e}$ & $92.27 \pm 1.30 \mathrm{a}$ \\
\hline 3 & 0.5 & 1.5 & 1.5 & $40.82 \pm 12.25 \mathrm{e}$ & $92.26 \pm 2.45 a$ \\
\hline 4 & 1 & 0.5 & 1 & $123.53 \pm 14.87 \mathrm{de}$ & $76.58 \pm 2.41 b c$ \\
\hline 5 & 1 & 1 & 1.5 & $163.59 \pm 16.09 \mathrm{cde}$ & $68.99 \pm 0.78 \mathrm{~cd}$ \\
\hline 6 & 1 & 1.5 & 0.5 & $247.85 \pm 42.91 c$ & $53.02 \pm 3.63 \mathrm{e}$ \\
\hline 9 & 1.5 & 1.5 & 1 & $282.28 \pm 20.81 b c$ & $46.49 \pm 2.89 \mathrm{e}$ \\
\hline Control & 0 & 0 & 0 & $527.52 \pm 63.55 a$ & \\
\hline $\mathrm{T} 1$ & 269.2 & 215.47 & 166 & & \\
\hline $\mathrm{T} 2$ & 198.58 & 189.18 & 214.96 & & \\
\hline $\mathrm{T} 3$ & 128.48 & 191.61 & 215.3 & & \\
\hline $\mathrm{X} 1$ & 89.73 & 71.82 & 55.33 & & \\
\hline
\end{tabular}

Note: T1, T2, and T3 mean the sums of all ZEA degradation rates at the levels of $0.50 \%, 1.00 \%$, and $1.50 \%$ respectively; $\mathrm{X} 1, \mathrm{X} 2$, and $\mathrm{X} 3$ mean the averages of all ZEA degradation rates at the levels of $0.50 \%, 1.00 \%$, and $1.50 \%$ respectively; $R$ represents the D-value between the maximum and minimum averages of each factor at different levels, and a bigger $R$ value indicates that the factor is more important for a higher ZEA degradation rate. Data with the same lowercase letters in the same columns are insignificantly different from each other $(p>0.05)$; while data with different lowercase letters in the same columns are significantly different from each other $(p<0.05)$; the same as below.

Table 2. Main effect analyses among different factors.

\begin{tabular}{cccccc}
\hline Sources & Sum of Squares & DF & Mean Square & $F$ & $p$ \\
\hline Corrected Model & 2808.72 & 6 & 468.12 & 73.68 & 0.0132 * \\
A & 2545.95 & 2 & 1272.98 & 200.35 & $0.0051^{*}$ \\
B & 83.97 & 2 & 41.99 & 6.61 & 0.1312 \\
C & 178.79 & 2 & 89.40 & 14.07 & 0.0661 \\
Error & 12.71 & 2 & 6.35 & & \\
Corrected total & 2821.42 & 8 & & & \\
\hline \multicolumn{7}{c}{ Note: “* shows significant differences. }
\end{tabular}

\subsection{ZEA Degradation by the Combined Probiotics and Cell-Free Extracts of A. oryzae}

For measuring the effect of combined probiotics with cell-free extracts of $A$. oryzae on ZEA degradation, the effectiveness of extracts from $A$. oryzae was first determined. Figure 1 indicates that the ZEA degradation rate was $88.16 \%$ after $24 \mathrm{~h}$ enzymatic hydrolysis $(p<0.05)$; thereafter, there was no significant difference among the different groups $(p>0.05)$, even though ZEA degradation rate reached $98.62 \%$ after $48 \mathrm{~h}$ enzymatic reaction. Table 3 indicated that the best ZEA degradation rate was $95.15 \%$ when the ratio between probiotics and cell-free extracts of $A$. oryzae was 2:1 $(p<0.05)$. According to this ratio, mycotoxin-biodegradation preparation (MBP) was made for the further pig feeding experiment. ZEA degradation rate of individual probiotics was lower than both combinations of probiotics and cell-free extracts of $A$. oryzae $(p<0.05)$, indicating the effectiveness of combination; however, there was no significant difference between single cell-free extracts and both combinations for ZEA degradation $(p>0.05)$. 


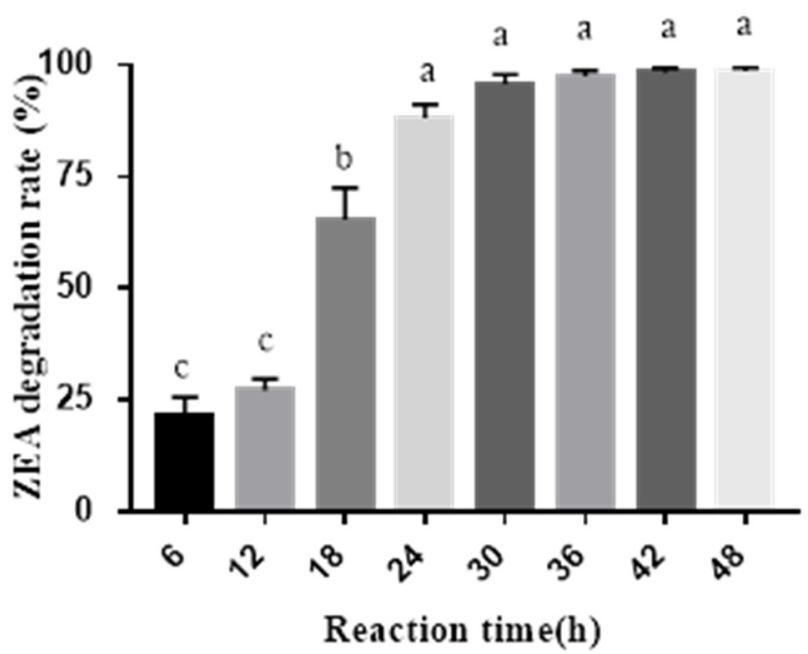

Figure 1. ZEA degradation by cell-free extracts of A. oryzae at different reaction times. Note: Data with the same lowercase letters in the bars are insignificantly different from each other $(p>0.05)$; while data with different lowercase letters in the bars are significantly different from each other $(p<0.05)$.

Table 3. ZEA degradation by the combined probiotics with cell-free extracts of $A$. oryzae for a $48 \mathrm{~h}$ reaction.

\begin{tabular}{cccc}
\hline Groups & Probiotics: Cell-free extracts of $A$. oryzae & ZEA Content $(\mu \mathrm{g} / \mathrm{L})$ & ZEA Degradation Rate $(\%)$ \\
\hline 1 & $1: 1$ & $120.57 \pm 21.56 \mathrm{c}$ & $89.89 \pm 1.81 \mathrm{a}$ \\
2 & $1: 2$ & $128.27 \pm 79.74 \mathrm{c}$ & $89.24 \pm 6.69 \mathrm{a}$ \\
3 & $1: 3$ & $64.31 \pm 83.73 \mathrm{c}$ & $94.60 \pm 7.02 \mathrm{a}$ \\
4 & $2: 1$ & $57.81 \pm 12.83 \mathrm{c}$ & $95.15 \pm 1.08 \mathrm{a}$ \\
5 & $2: 3$ & $108.19 \pm 28.55 \mathrm{c}$ & $90.92 \pm 2.39 \mathrm{a}$ \\
6 & $3: 1$ & $84.05 \pm 73.25 \mathrm{c}$ & $92.95 \pm 6.14 \mathrm{a}$ \\
7 & $3: 2$ & $102.72 \pm 72.17 \mathrm{c}$ & $91.83 \pm 6.05 \mathrm{a}$ \\
9 & $1: 0$ & $349.38 \pm 34.13 \mathrm{~b}$ & $70.69 \pm 2.86 \mathrm{~b}$ \\
Control & $0: 1$ & $170.59 \pm 64.49 \mathrm{c}$ & $85.69 \pm 5.41 \mathrm{a}$ \\
\hline
\end{tabular}

Note: Data with the same lowercase letters in the same columns are insignificantly different from each other $(p>0.05)$; while data with different lowercase letters in the same columns are significantly different from each other $(p<0.05)$.

\subsection{Effect of MBP on Pig Growth Performance and Nutrient Digestibility}

In order to determine the effect of MBP on alleviating ZEA for pig production performance, feeding experiments were conducted. Table 4 indicates that there were no significant differences in average daily gain (ADG), average daily feed intake (ADFI), feed conversion rate (F/G), and digestibility of crude protein $(\mathrm{CP})$, crude fat $(\mathrm{CF})$, phosphorus $(\mathrm{P})$, and calcium $(\mathrm{Ca})$ among the 5 groups $(p>0.05)$. However, it showed that the above parameters could be improved by MBP addition in groups D and E, compared to group B. 
Table 4. Effect of mycotoxin-biodegradation preparation (MBP) on growth performance and nutrient digestibility of pigs exposed to ZEA.

\begin{tabular}{cccccc}
\hline Items & Group A & Group B & Group C & Group D & Group E \\
\hline Initial weight $(\mathrm{Kg})$ & $34.83 \pm 1.06$ & $34.92 \pm 1.34$ & $35.17 \pm 2.35$ & $34.88 \pm 1.27$ & $34.83 \pm 1.89$ \\
Final weight $(\mathrm{Kg})$ & $90.00 \pm 4.23$ & $83.58 \pm 4.47$ & $82.63 \pm 1.80$ & $88.54 \pm 2.47$ & $88.33 \pm 3.70$ \\
ADG $(\mathrm{Kg})$ & $0.9211 \pm 0.0812$ & $0.8088 \pm 0.0811$ & $0.7886 \pm 0.0304$ & $0.8913 \pm 0.0412$ & $0.8908 \pm 0.0321$ \\
ADFI (Kg) & $2.612 \pm 0.151$ & $2.402 \pm 0.171$ & $2.389 \pm 0.080$ & $2.614 \pm 0.140$ & $2.542 \pm 0.079$ \\
F/G & $2.842 \pm 0.100$ & $2.963 \pm 0.121$ & $3.019 \pm 0.213$ & $2.914 \pm 0.020$ & $2.771 \pm 0.169$ \\
CP digestibility (\%) & $89.73 \pm 0.16$ & $91.97 \pm 0.94$ & $89.53 \pm 1.67$ & $89.23 \pm 1.25$ & $90.67 \pm 1.93$ \\
CF digestibility (\%) & $76.99 \pm 3.94$ & $80.87 \pm 5.56$ & $82.63 \pm 4.28$ & $78.41 \pm 3.11$ & $75.32 \pm 1.22$ \\
P digestibility (\%) & $88.19 \pm 0.42$ & $87.67 \pm 0.48$ & $86.38 \pm 1.58$ & $87.21 \pm 0.20$ & $88.98 \pm 0.07$ \\
Ca digestibility (\%) & $78.83 \pm 0.22$ & $77.51 \pm 0.75$ & $77.44 \pm 0.09$ & $76.48 \pm 1.19$ & $77.21 \pm 0.89$ \\
\hline
\end{tabular}

Note: Data without lowercase letters in the same rows are insignificantly different from each other $(p>0.05)$. Group A: control; Group B: $300.00 \mu \mathrm{g} / \mathrm{kg}$ ZEA; Groups C, D, and E: $300.00 \mu \mathrm{g} / \mathrm{kg}$ ZEA plus $0.05 \%, 0.10 \%$, and $0.15 \% \mathrm{MBP}$, respectively. Note: average daily gain (ADG), average daily feed intake (ADFI), feed conversion rate (F/G), and digestibility of crude protein $(\mathrm{CP})$ and crude fat $(\mathrm{CF})$.

\subsection{Pig Gut Microbiota Affected by MBP}

The DGGE profile can reflect the structure of the gut bacterial community, and the number of bands indicates the richness of phylogenetic types. Figure 2 indicates that the numbers of discernible microbial bands in gilt large intestines were 18, 24, and 25 in group A; 18, 20, and 27 in group B; and 19, 23 , and 26 in group D. The universal bands were 14,13 , and 13 in groups A, B, and D, respectively. The sizes of bands were about $220 \mathrm{bp}$. After statistical analysis of the bands, there was no significant difference in microbial richness among the three groups in Figure 3. The gut microbial similarity coefficient analysis in Figure 4 showed that similarity coefficients were $57.2 \%-72.9 \%$ in group A, $38.3 \%-72.8 \%$ in group $\mathrm{B}$, and $69.1 \%-73.8 \%$ in group $\mathrm{D}$, indicating that the gut microbiota was more stable by MBP addition in group D.

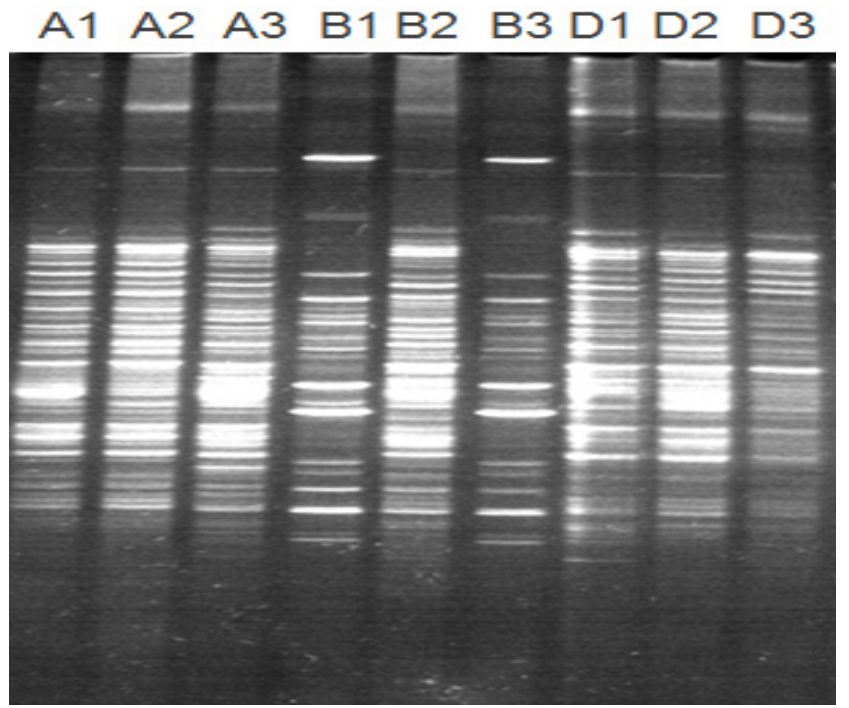

Figure 2. The electrophoresis diagram of DGGE in gilt large intestines. Note: Lanes A1-A3, contents of large intestine in group A; Lanes B1-B3, contents of large intestine in group B; Lanes D1-D3, contents of large intestine in group D. 


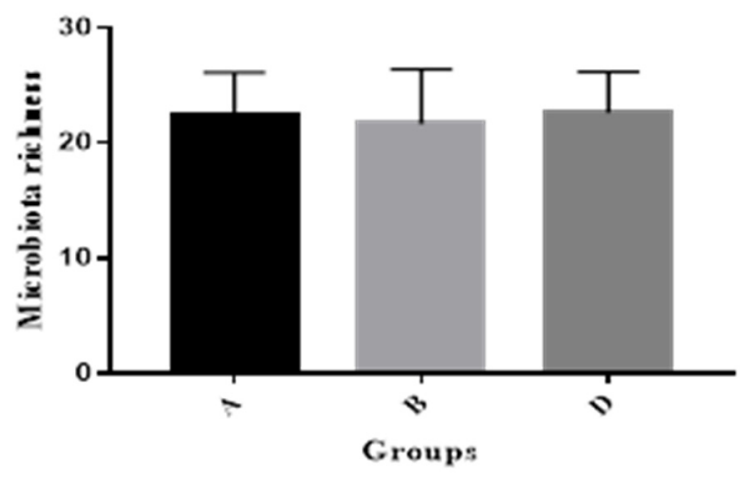

Figure 3. Microbial richness calculated by the number of bands in the electrophoresis diagram of DGGE.

\begin{tabular}{cccccccccc}
\hline Lane & A1 & A2 & A3 & B1 & B2 & B3 & D1 & D2 & D3 \\
\hline A1 & 100.0 & & & & & & & & \\
A2 & 57.2 & 100.0 & & & & & & & \\
A3 & 58.8 & 72.9 & 100.0 & & & & & & \\
B1 & 23.2 & 31.8 & 38.3 & 100.0 & & & & & \\
B2 & 60.0 & 64.7 & 72.8 & 44.7 & 100.0 & & & & \\
B3 & 27.5 & 26.3 & 35.8 & 55.6 & 39.8 & 100.0 & & & \\
D1 & 47.5 & 64.7 & 68.9 & 45.1 & 68.0 & 34.9 & 100.0 & & \\
D2 & 45.2 & 65.5 & 72.7 & 38.7 & 66.9 & 25.4 & 73.8 & 100.0 & \\
D3 & 52.6 & 63.0 & 65.8 & 32.0 & 62.6 & 19.1 & 69.2 & 69.1 & 100.0 \\
\hline
\end{tabular}

Figure 4. The microbial similarity coefficients in different samples.

\subsection{The Vulvar Area and Serum Parameters}

Gilt vulvar area can reflect the effect of ZEA on female pig reproduction status. The effect of MBP on alleviating gilt vulvar area caused by ZEA in Figure 5 showed that, during the first $15 \mathrm{~d}$, the vulvar area in group A increased slightly, while the other groups increased greatly, especially for group B. Fifteen days later, the vulvar area in each group increased slightly, and the order of vulvar area was: group $\mathrm{B}>$ group $\mathrm{C}>$ groups $\mathrm{D}$ and $\mathrm{E}>$ group $\mathrm{A}$, indicating the effectiveness of MBP for weakening ZEA detriments.

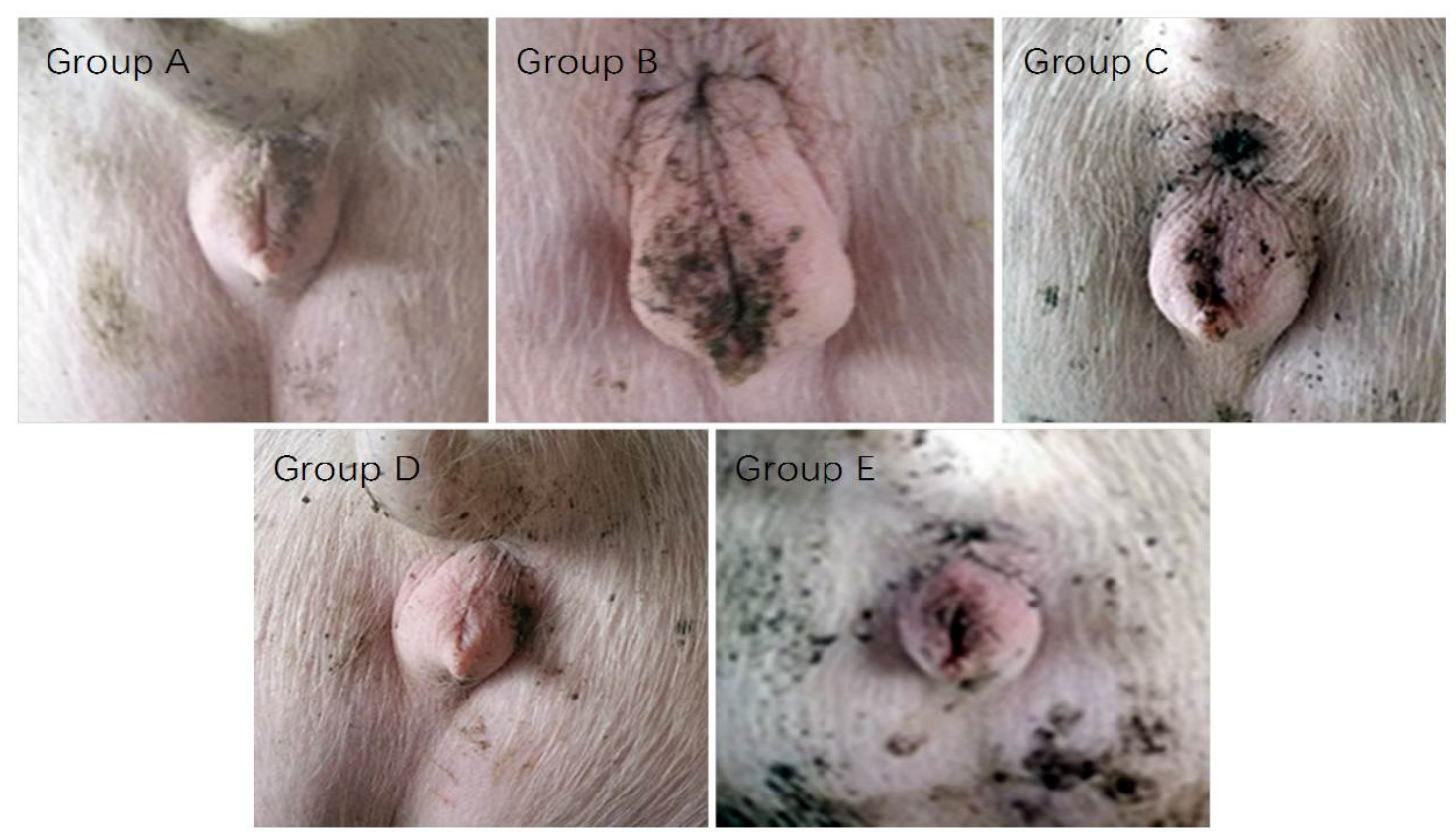

Figure 5. Effect of MBP on gilt vulvar representation. 
In addition, ZEA or MBP had no significant effect on serum biochemical parameters such as urea nitrogen (UN), total cholesterol (TC), glucose (GLU), triglyceride, high-density lipoprotein (HDL), low-density lipoprotein (LDL), total protein (TP), albumin (ALB), globulin (GLO), albumin and globulin ratio (A/G), alanine aminotransferase (ALT), aspartate aminotransferase (AST), alkaline phosphatase (ALP), immunoglobulin G (IgG), immunoglobulin M (IgM), glutathione peroxidase (GSH-Px), and estradiol $\left(\mathrm{E}_{2}\right)$. It can be concluded that ZEA or MBP could not cause significant effects on the normal physiological and metabolic status of pigs in this study.

\subsection{The Relative Organ Weight and ER $\alpha$ mRNA Abundance in Ovaries and the Uterus}

ZEA may influence the relative organ weight and ER $\alpha$ mRNA abundance for female pigs. However, Table 5 shows that there was no significant difference for relative organ weight and ER $\alpha$ mRNA abundance in ovaries and the uterus among groups $\mathrm{A}, \mathrm{B}$, and $\mathrm{D}(p>0.05)$, which showed that $300.00 \mu \mathrm{g} / \mathrm{kg}$ ZEA in pig diets was not enough to cause significant changes in relative organ weight and $\mathrm{ER} \alpha \mathrm{mRNA}$ abundance in ovaries and the uterus, even though MBP addition could alleviate ZEA hazards to some extent.

Table 5. Effect of MBP on serum E2 content, relative organ weight, and ER $\alpha$ mRNA in ovaries and the uterus.

\begin{tabular}{cccc}
\hline Items & Group A & Group B & Group D \\
\hline Heart $(\mathrm{g} / \mathrm{Kg})$ & $3.241 \pm 0.100$ & $3.177 \pm 0.311$ & $3.616 \pm 0.194$ \\
Liver $(\mathrm{g} / \mathrm{Kg})$ & $15.97 \pm 1.81$ & $16.33 \pm 0.80$ & $18.67 \pm 1.67$ \\
Spleen $(\mathrm{g} / \mathrm{Kg})$ & $1.365 \pm 0.249$ & $1.605 \pm 0.041$ & $1.703 \pm 0.164$ \\
Kidney $(\mathrm{g} / \mathrm{Kg})$ & $2.960 \pm 0.172$ & $2.967 \pm 0.221$ & $3.432 \pm 0.496$ \\
Uterus $(\mathrm{g} / \mathrm{Kg})$ & $1.245 \pm 0.752$ & $1.932 \pm 0.587$ & $1.673 \pm 0.318$ \\
Serum E2 $(\mathrm{pg} / \mathrm{ml})$ & $109.03 \pm 8.29$ & $112.48 \pm 15.75$ & $103.88 \pm 5.06$ \\
ER $\alpha$ mRNA abundance in ovaries & $0.7899 \pm 0.1021$ & $1.171 \pm 0.141$ & $1.171 \pm 0.122$ \\
ER $\alpha$ mRNA abundance in uterus & $1.010 \pm 0.086$ & $1.111 \pm 0.153$ & $1.071 \pm 0.191$ \\
\hline Note: Data without lowercase letters in the same rows are insionificantly different from each other $(p>0.05)$
\end{tabular}

Note: Data without lowercase letters in the same rows are insignificantly different from each other $(p>0.05)$.

\subsection{ZEA Concentrations in Serum, Relative Tissues, and Gut}

In order to realize the status of ZEA metabolism and deposit for pigs, the ZEA distribution was measured. Table 6 shows that residual ZEA in serum, longissimus dorsi, uterus, and liver in groups A, $\mathrm{B}$, and D was not detected. ZEA concentrations in jejunal contents in groups $\mathrm{A}$ and D were $89.47 \%$ and $80.07 \%$ lower than that in group B $(p<0.05)$. ZEA concentrations in the large intestine in groups A and $\mathrm{D}$ were $68.57 \%(p<0.05)$ and $12.79 \%(p>0.05)$ lower than that in group $\mathrm{B}$, respectively, indicating the effectiveness of MBP for ZEA degradation.

Table 6. Effect of MBP on ZEA concentrations in pig serum, tissues, and gut ( $\mu \mathrm{g} / \mathrm{Kg})$.

\begin{tabular}{cccc}
\hline Items & Group A & Group B & Group D \\
\hline Serum & - & - & - \\
Longissimus dorsi & - & - & - \\
Uterus & - & - & - \\
Liver & - & - & $22.03 \pm 8.20 \mathrm{~b}$ \\
Contents in jejunum & $11.64 \pm 0.27 \mathrm{~b}$ & $110.54 \pm 16.19 \mathrm{a}$ & $120.55 \pm 18.87 \mathrm{a}$ \\
\hline
\end{tabular}

Note: Data with the same lowercase letters in the same rows are insignificantly different from each other $(p>0.05)$; while data with different lowercase letters in the same rows are significantly different from each other $(p<0.05)$. "—" indicates no detection. 


\section{Discussion}

As one of the most ubiquitous mycotoxins, ZEA has caused serious harm to animals and humans and has led to a great waste of food resources every year [21]. There are two ways to solve this problem. One way is to inhibit ZEA production from microbes, which is hard to conduct due to the difficult control of ZEA-excreting microbes in the environment; another way is to eliminate ZEA harm to animals and humans by chemical, physical, and biodegradable methods [12-15]. Although physical and chemical methods can eliminate ZEA harm, they also reduce the nutritional value of food and pollute the environment. Many researchers have indicated that ZEA biodegradation or absorption by microbes and mycotoxin-degrading enzymes is the most effective method [16,17,22,23].

It was found that the peroxiredoxin gene from Acinetobacter sp. SM04 was cloned in Escherichia coli BL21 to excrete one recombinant protein for ZEA detoxification [24]. Saccharomyces cerevisiae and B. subtilis have been found to be able to degrade ZEA around 90\% $[25,26]$. Broomyces pink and B. subtilis were reported to open the ZEA lactone ring to form nontoxic compounds by hydrolyzing lactone bonds $[27,28]$. In order to increase the ZEA degradation rate, two strains of B. subtilis and one strain of C. utilis with good ZEA degradation abilities have been selected and combined with ZEA degradation enzymes from A. oryzae in this study.

A. oryzae is one kind of microbe that produces complex enzymes, which will help to increase nutrient availability and degrade mycotoxins. It was found that $A$. oryzae could convert ZEA into other metabolites and reduce the toxicity of toxins [29]. Another report showed that the deoxynivalenol degradation rate was over $92 \%$ after $A$. oryzae was inoculated with corn culture medium for $21 \mathrm{~d}$ [30]. In this research, cell-free extracts of $A$. oryzae could degrade ZEA by $98.62 \%$ after $48 \mathrm{~h}$ enzymatic reaction, which was better than the previous report. When cell-free extracts of $A$. oryzae were combined with the probiotics, the ZEA degradation rate was higher than the individual, indicating that there was a good cooperation between them. This result corresponds with the previous report for aflatoxin removal [31]. Generally, the probiotics are able to regulate gastrointestinal microbiota for animal health, except for its ZEA-removing ability. Therefore, the combination of beneficial bacteria and A. oryzae extracts will have great applications in the fields of animal production and food and feed processing.

ZEA is widely distributed in all kinds of grain crops and feedstuffs. The prevention and removal of ZEA pollution of grain has become a hotspot for researchers. It was found that the growth performance of weaned piglets fed with $1000 \mu \mathrm{g} / \mathrm{Kg}$ ZEA diet for $24 \mathrm{~d}$ and the young gilts fed with $1.5-2.0 \mathrm{mg} / \mathrm{kg}$ ZEA diet for $28 \mathrm{~d}$ had no significant changes [32,33]. In this study, after feeding with $300 \mu \mathrm{g} / \mathrm{Kg}$ ZEA diet for $60 \mathrm{~d}$, ADG, ADFI, F/G, and nutrient digestibility of young pigs had no significant difference regardless of MBP addition or not. It is possible that this concentration of ZEA added in the diet was not enough to retard pig growth even though it may influence reproduction for female pigs.

This study showed that MBP addition was able to increase gut microbial similarity coefficients to help maintain gut microbial balance for pig health, in agreement with the former research, in which it was reported that Saccharomyces cerevisiae subsp. boulardii strain had the potential as feed additives to modulate bacterial populations associated with gut health for piglets [34].

After the diets contaminated with ZEA are fed to animals, ZEA will have three metabolic pathways: (1) ZEA is absorbed in the gut and remains in the animal's body; (2) it is degraded by the gut microbes and enzymes; and (3) some ZEA will be discharged with the feces. It was found that the residual amount of ZEA in gilt livers increased significantly when dietary ZEA contents were 500 or 2000 $\mu \mathrm{g} / \mathrm{Kg}$ [35]. However, ZEA was not detected in serum, longissimus dorsi, the uterus, and liver in this study, inconsistent with the above. This may be due to the low ZEA content $(300 \mu \mathrm{g} / \mathrm{Kg})$ in pig diets. This research showed that ZEA concentrations in jejunal contents in group $B$ was significantly higher than that in group A and group D, indicating that part of ZEA was eliminated by MBP in the gastrointestinal tract, which proved the effectiveness of MBP for degrading ZEA in pig guts.

Serum ALT, AST, and ALP are important indicators to measure the degree of liver lesions. Serum $\operatorname{IgG}$ and IgM are the main factors that participate in the humoral immune response. Their normal levels in this study indicated that liver cells and immune systems have not been damaged by ZEA at 
$300 \mu \mathrm{g} / \mathrm{Kg}$ dosage. The previous report showed that long-term exposure to a low dose of ZEA had no significant negative effect on serum ALT, AST, ALP, and E2 levels in pigs [36], which is in agreement with this study. The organ indexes of heart, liver, kidney, and spleen were not significantly changed by feeding the weaned piglets with $316 \mu \mathrm{g} / \mathrm{Kg}$ ZEA diets [37], which corresponds with this study. The reason may be due to the low ZEA dose in pig diets.

The chemical structure of ZEA is the same as estrogen; therefore, ZEA can competitively bind estrogen receptors to cause reproduction disorders, in which the red and swelling vulva of female pig is the common apparent symptom. This research showed that $300 \mu \mathrm{g} / \mathrm{Kg} \mathrm{ZEA}$ could cause a red and swelling vulva; however, MBP addition was able to alleviate the symptoms, in agreement with the previous research with Bacillus addition [38]. It was found that MBP was better than only Bacillus subtilis for degrading ZEA and keeping the microbiota stable in the pig gut [38].

It was found that the relative expression of estrogen receptor gene ER $\alpha$ mRNA in the ZEA group was significantly higher than that in control group [39]. Another research study showed that the serum E2 of females was significantly decreased by the addition of $1.05 \mathrm{mg} / \mathrm{kg}$ ZEA in diets [32]. Generally, ZEA could cause DNA double-strand breaks and affect the proliferation of granulosa cells, and the addition of an estrogen receptor antagonist could improve this symptom, indicating that ZEA could damage granulosa cells through the estrogen receptor pathway [40]. It was reported that the relative expression levels of ER $\alpha$ genes in brain, liver, and gonads were not significantly affected by low doses of ZEA, but they were significantly affected by high doses of ZEA. This process changed the HPG axis by altering gene expression of the steroid hormone-encoding gene to affect reproductive function [41]. In this study, the relative expression of estrogen receptor gene ER $\alpha$ mRNA in ovaries and the uterus was not significantly different among the three groups, which does not correspond with the above results. The reason may be due to the low levels of ZEA in the diet in this study.

\section{Conclusions}

The combination of beneficial microbes (B. subtilis SP1, B. subtilis SP2, C. utilis) and cell-free extracts from $A$. oryzae could degrade ZEA effectively in vitro. MBP addition could alleviate ZEA negative effects in gilts by decreasing vulvar swelling, improving ZEA degradation in the jejunum, and keeping normal growth performance and gut microbiota stable.

\section{Materials and Methods}

\subsection{Probiotics and Experimental Materials}

B. subtilis SP1, B. subtilis SP2, C. utilis, and A. oryzae with high ZEA-degrading ability were purchased from China General Microbiological Culture Collection Center (CGMCC, Beijing, China). ZEA was purchased from Sigma-Aldrich (St. Louis, MO., USA) and diluted in methanol as stock solution $(100 \mu \mathrm{g} / \mathrm{mL})$. PBS buffer was prepared according to the previous protocol [42]. The compositions of media for B. subtilis, C. utilis, and A. oryzae incubations were prepared according to the published protocols $[43,44]$. Then, three kinds of probiotics were harvested and stored at $4{ }^{\circ} \mathrm{C}$.

\subsection{Degradation of ZEA by Probiotic Incubation}

The visible counts of three kinds of microbes were adjusted to $1.0 \times 10^{8} \mathrm{CFU} / \mathrm{mL}$, respectively. The orthogonal design ( $5 \mathrm{~mL}$ reaction system) with three factors (B. subtilis SP1, B. subtilis SP2, and C. utilis) and three levels $(25,50$, and $75 \mu \mathrm{L})$ were used to investigate the effect of beneficial microbes on degrading ZEA. Each group contained $1 \mu \mathrm{g} / \mathrm{mL}$ ZEA. The contents of ZEA in the samples were determined by enzyme-linked immunosorbent assay (ELISA) according to Huang's report [44], which was highly consistent with high-performance liquid chromatography (HPLC). ZEA degradation rates were calculated according to the following formula: ZEA degradation rate $=(1-\mathrm{ZEA}$ concentration in treatment/ZEA concentration in control) $\times 100 \%$. All experiments were conducted in triplicate. 


\subsection{Preparation of Cell-Free Extracts from A. oryzae}

A. oryzae was inoculated in solid medium at $30{ }^{\circ} \mathrm{C}$ for $3 \mathrm{~d}$. After incubation, $15 \mathrm{~g}$ solid incubation was mixed with $300 \mathrm{~mL}$ physiological saline and put in a rotary shaker at $180 \mathrm{rpm}$ for $2 \mathrm{~h}$. The mixture was filtered with eight-layer gauze, centrifuged at 10,000 $\mathrm{g}$ for $10 \mathrm{~min}$, passed through Whatman No.4 filter paper (20 to $25 \mu \mathrm{m}$ pore diameters), and filtered with $0.22 \mu \mathrm{m}$ Minisart High-flow filter (Sartorius Stedim Biotech Gmbh, Goettingen, Germany). Finally, it was stored at $4{ }^{\circ} \mathrm{C}$ for further use.

The final volumes of $60 \mathrm{~mL}$ filtrates with an initial ZEA concentration of $1 \mu \mathrm{g} / \mathrm{mL}$ in $250 \mathrm{~mL}$ conical flasks were incubated at $37^{\circ} \mathrm{C}$ in a rotary shaker at $180 \mathrm{rpm}$, and the samples were collected after $0,6,12,18,24,30,36,42$, and $48 \mathrm{~h}$ incubation, respectively. The ZEA degradation rates were measured at different times. The ZEA degradation activity $(31.0 \mathrm{U} / \mathrm{L})$ from cell-free extracts of $A$. oryzae was determined with the previous protocol [42] and modified as the following: the amount of enzyme that could degrade $1 \mathrm{ng}$ ZEA per min at $\mathrm{pH} 7.0$ and $37^{\circ} \mathrm{C}$ was defined as one unit.

\subsection{ZEA Degradation by Probiotics Combined with Cell-Free Extracts of A. oryzae}

The probiotics for degrading ZEA were added in YPD medium at the above ratio. The probiotics and cell-free extracts from $A$. oryzae were mixed at the volume ratios of 1:1, 1:2, 1:3, 2:1, 2:3, 3:1, 3:2, 1:0, and $0: 1$ as treatment groups. The final volume of the reaction system was adjusted to $3 \mathrm{~mL}$ with YPD medium. All the groups received $30 \mu \mathrm{L} \mathrm{ZEA}(100 \mu \mathrm{g} / \mathrm{mL})$, were incubated at $37^{\circ} \mathrm{C}$ in a rotary shaker at $180 \mathrm{rpm}$ for $48 \mathrm{~h}$, and were finally put in boiling water for $30 \mathrm{~min}$ to terminate the reaction.

\subsection{Animals and Management}

A total of 120 young pigs (Duroc $\times$ Landrace $\times$ Yorkshire) at the ages of 78-84 $\mathrm{d}$ were randomly divided into 5 groups, with 3 replicates in each group and 8 pigs (half male and half female) in each replicate. All animals used in this experiment were managed according to the guidelines of Animal Care and Use Ethics Committee in Henan Agricultural University (SKLAB-B-2010-003-01). The pigs were provided with a corn/soybean basal diet formulated to meet pig nutrient requirements according to the NRC (2012) [45]. The diets and water were provided ad libitum. The total experimental period was $60 \mathrm{~d}$. After the feeding experiment, three gilts from groups A, B, and D were slaughtered for further analyses, respectively. Body weight and feed intake were recorded. ZEA used in animal feeding experiments was purchased from Wuhan 3B Scientific Corporation (Wuhan, China). The experimental designs were as follows:

Group A: Basal diet with $86.19 \mu \mathrm{g} / \mathrm{kg}$ ZEA

Group B: Basal diet containing $300.00 \mu \mathrm{g} / \mathrm{kg}$ ZEA

Group C: Basal diet containing $300.00 \mu \mathrm{g} / \mathrm{kg}$ ZEA and 0.05\% MBP

Group D: Basal diet containing $300.00 \mu \mathrm{g} / \mathrm{kg}$ ZEA and 0.10\% MBP

Group E: Basal diet containing $300.00 \mu \mathrm{g} / \mathrm{kg}$ ZEA and $0.15 \%$ MBP

\subsection{Nutrient Digestibility Measurement}

Fecal samples were taken without contamination from each of 5 pigs in each group for $3 \mathrm{~d}$ at the end of the experiment. The individual fecal sample was mixed, selected, and stored at -20 and $4{ }^{\circ} \mathrm{C}$, respectively. The fecal samples stored at $-20^{\circ} \mathrm{C}$ were dried to determine nutrient digestibility. $\mathrm{CP}, \mathrm{CF}$, $\mathrm{Ca}$, and $\mathrm{P}$ in diets and feces were measured with Kjeldahl, ether extract, potassium permanganate $\left(\mathrm{KMnO}_{4}\right)$, and ammonium molybdate $\left(\left(\mathrm{NH}_{4}\right)_{6} \mathrm{Mo}_{7} \mathrm{O}_{24}\right)$ protocols, respectively [46]. The insoluble ash of hydrochloric acid in feed and feces was used as an indicator to calculate the nutrient digestibility with the following formula: Nutrient digestibility $=$ (nutrient content in diets - nutrient content in feces)/nutrient content in diets $\times 100 \%$. 


\subsection{Vulvar Area Measurement of Gilts}

From the beginning of the experiment, vulvar areas of gilts were observed every day, and six gilts in each group were selected and measured at $15,30,45$, and $60 \mathrm{~d}$. The measurement method was based on a previous report, the vulvar area $=\pi \times$ vulvar width $\times$ vulvar length $/ 4$ [38].

\subsection{Serum Parameter Determination}

Blood samples were taken from the anterior vena cava of three pigs in each group. After the blood was tilted at room temperature for $3 \mathrm{~h}$, the serum was collected by Transferpettor and stored in a centrifuge tube at $-20^{\circ} \mathrm{C}$ for further analysis. The serum biochemical parameters such as UN, TC, GLU, triglycerides, HDL, LDL, TP, ALB, GLO, A/G, ALT, AST, ALP, IgG, and IgM were measured with a 7600-020 Automatic Analyzer (Hitachi Ltd., Tokyo, Japan) in the Biochemical Laboratory of Zhengzhou University, Zhengzhou, China. The concentrations of GSH-Px and $\mathrm{E}_{2}$ were respectively measured by ELISA quantification kits (Nanjing Jiancheng Bioengineering Institute, Nanjing, China).

\subsection{Relative Organ Weight and ER $\alpha$ mRNA Abundance in Ovaries and the Uterus}

After the feeding experiment, 3 gilts from 3 representative groups (groups A, B, and D) were selected and slaughtered, respectively. The gut contents were taken and frozen for further gut microbiota analysis, and the organs were taken and weighed. The formula for calculating the organ index was as follows: organ index = organ weight $(\mathrm{g}) /$ living weight $(\mathrm{Kg})$. Some parts of ovaries and the uterus were stored in liquid nitrogen for mRNA abundance analyses.

In order to measure the expression levels of ER $\alpha$ in ovaries and the uterus, the total RNA was extracted by using RNAiso Plus kits (TaKaRa, Dalian, China). The result was checked with $1 \%$ agarose gel electrophoresis. The reaction system for cDNA consisted of $2 \mu \mathrm{L} 4 \times$ gDNA wiper Mix, $4 \mu \mathrm{L}$ RNA template, and $2 \mu \mathrm{L}$ RNase-free water. It was kept at $42{ }^{\circ} \mathrm{C}$ for $2 \mathrm{~min}$, mixed with $2 \mu \mathrm{L} 5 \times$ HiScript ${ }^{\circledR}$ IIqRT SuperMixII (Vazyme Biotech Co., Ltd., Nanjing, China), and then kept at $25^{\circ} \mathrm{C}$ for $10 \mathrm{~min}, 50^{\circ} \mathrm{C}$ for $30 \mathrm{~min}$, and $85^{\circ} \mathrm{C}$ for $5 \mathrm{~min}$. The cDNA samples were stored at $-20^{\circ} \mathrm{C}$ for further use. The qPCR reaction consisted of $10.0 \mu \mathrm{L}$ AceQ ${ }^{\circledR}$ qPCR SYBR ${ }^{\circledR}$ Green Master Mix, $0.4 \mu \mathrm{L}$ ROX, $0.4 \mu \mathrm{L}$ Primer F $(10 \mu \mathrm{M}), 0.4 \mu \mathrm{L}$ Primer R $(10 \mu \mathrm{M}), 2.0 \mu \mathrm{L}$ cDNA, and $6.8 \mu \mathrm{L}$ RNase-free water (Vazyme Biotech Co., Ltd., Nanjing, China). The primers for ER $\alpha$ and glyceraldehyde-3-phosphate dehydrogenase (GAPDH) genes were as follows: Forward 5'-GACAGGAACCAGGGCAAGT-3', Reverse 5'-ATGATGGATT TGAGGCACAC- $3^{\prime}$ for ER $\alpha$; Forward 5'-ATGGTGAAGGTCGGAGTGAA-3', Reverse 5'-CGTGGGTGGAATCATACTGG-3' for GAPDH. The thermal program of qPCR consisted of 1 cycle at $95^{\circ} \mathrm{C}$ for $10 \mathrm{~min}, 40$ cycles of $95^{\circ} \mathrm{C}$ for $15 \mathrm{~s}, 57^{\circ} \mathrm{C}$ for $30 \mathrm{~s}$, and then stored at $37^{\circ} \mathrm{C}$ for $30 \mathrm{~s}$. Gene-specific amplification was determined by a melting curve analysis and agarose gel electrophoresis. The cycle threshold value was analyzed (iQ5 detection System) and transformed to a relative quantity using the $2^{-\Delta \Delta C T}$ method with the highest quantity scaled to 1 [47]. GAPDH gene was used as the reference gene for stability of expression to standardize the relative expression of the gene investigated.

\subsection{DNA Extraction of Gut Bacteria and PCR-DGGE}

About $1.0 \mathrm{~g}$ of gut sample from the large intestine was defrosted, put into a $10 \mathrm{~mL}$ centrifuge tube, washed with $5 \mathrm{~mL}$ PBS, and centrifuged at $500 \mathrm{~g}$ at $4{ }^{\circ} \mathrm{C}$ for $5 \mathrm{~min}$ to collect the supernatant according to the previous protocol [48]. The washing step was repeated 3 times. The supernatants from 3 washing steps were mixed together and centrifuged at $8000 \mathrm{~g}$ for $5 \mathrm{~min}$ to collect the pellet. The bacterial DNA was extracted with MiniBEST Bacterial Genomic DNA Extraction Kit (TaKaRa, Dalian, China), dissolved in $100 \mu \mathrm{L} \mathrm{TE}$, and stored at $-20^{\circ} \mathrm{C}$ as the template for PCR amplification.

The primers of V3 regions of bacterial 16S rRNA genes [49] were F341: CGCCCGCCGCGCGCGGCGGGCGGGGCGGGGGCACGGGGGGCC TACGGGAGGCAGCAG, and R518: ATTACCGCGGCTGCTGG. The PCR system $(50 \mu \mathrm{L})$ consisted of $25 \mu \mathrm{L}$ Taq Master Mix, $5 \mu \mathrm{L}$ extracted gut DNA, $1 \mu \mathrm{L}$ primer F341-GC $(10 \mu \mathrm{M}), 1 \mu \mathrm{L}$ R518 $(10 \mu \mathrm{M})$, and $18 \mu \mathrm{L}$ RNase-free water 
(Beijing Comwin Biotech Co., Ltd. Beijing, China). The program consisted of initial DNA denaturation at $95^{\circ} \mathrm{C}$ for $5 \mathrm{~min}, 35$ cycles of $95^{\circ} \mathrm{C}$ for $30 \mathrm{~s}, 55^{\circ} \mathrm{C}$ for $30 \mathrm{~s}, 72{ }^{\circ} \mathrm{C}$ for $40 \mathrm{~s}$, and a final extension at $72{ }^{\circ} \mathrm{C}$ for $10 \mathrm{~min}$. The PCR products were detected by $1.5 \%$ agarose gel electrophoresis (Beijing Solarbio Science \& Technology Co., Ltd., Beijing, China).

The PCR products were separated in $8 \%$ polyacrylamide gel containing a $35 \%$ to $60 \%$ gradient of urea and formamide increasing in the direction of electrophoresis. Electrophoresis was initiated by prerunning at a voltage of $200 \mathrm{~V}$ for $10 \mathrm{~min}$ and then at a constant voltage of $90 \mathrm{~V}$ for $14 \mathrm{~h}$ at $60^{\circ} \mathrm{C}$. After electrophoresis, the gel was stained with $0.5 \mu \mathrm{g} / \mathrm{mL}$ ethidium bromide for $30 \mathrm{~min}$ and then washed with deionized water for $10 \mathrm{~min}$.

DGGE gels were analyzed using the software of Quantity One 4.6.6 (BioRad, California, USA, 2017). Microbial similarity coefficients (SC) between DGGE profiles were determined as follows: $\mathrm{SC}=2 \times \mathrm{J} /(\mathrm{Nx}+\mathrm{Ny})$, where $\mathrm{Nx}$ is the number of DGGE bands in lane $\mathrm{x}, \mathrm{Ny}$ represents the number of DGGE bands in lane $y$, and $\mathrm{J}$ is the number of common DGGE bands [50].

\subsection{Determination of ZEA Content in Serum and Tissues}

Longissimus dorsi, liver, and uterus tissues were ground into powder with liquid nitrogen. A total of $1 \mathrm{~mL}$ serum or $5 \mathrm{~g}$ samples were added to $25 \mathrm{~mL} 70 \%$ methanol, shaken for $3 \mathrm{~min}$, centrifuged at $10,000 \mathrm{~g}$ for $5 \mathrm{~min}$, then $1 \mathrm{~mL}$ supernatant was mixed with $1 \mathrm{~mL}$ deionized water for further determination. The ZEA contents in all samples were measured by RIDASCREEN ${ }^{\circledR}$ FAST ZEA SC test kit (R-Biopharm, Darmstadt, Germany).

\subsection{Statistical Analyses}

The experimental data were analyzed as a single factor design by analysis of variance (ANOVA) using IBM SPSS-Statistics Program 20.0 (IBM, New York, NY, USA, 2012), and they are expressed as means and standard errors (SEs). The means were evaluated with Tukey's multiple range test, and differences were considered statistically significance at $p<0.05$.

Author Contributions: C.L. and Q.Y. conceived and designed the experiments; W.H., C.L. and T.G. performed the experiments; J.C. and P.W. analyzed the data; X.D. and F.L. contributed reagents/materials/analysis tools; C.L. and Q.Y. wrote the paper.

Funding: This research was funded by the Natural Science Foundation of Henan Province (182300410029), and the Henan Key Scientific and Technological Project (171100110500).

Conflicts of Interest: The authors declare that there are no conflicts of interest associated with this research.

\section{References}

1. Caldwell, R.W.; Tuite, J.; Stob, M.; Baldwin, R. Zearalenone production by Fusarium species. Appl. Microbiol. 1970, 20, 31-34. [PubMed]

2. Takemura, H.; Shim, J.Y.; Sayama, K.; Tsubura, A.; Zhu, B.T.; Shimoi, K. Characterization of the estrogenic activities of zearalenone and zeranol in vivo and in vitro. J. Steroid Biochem. Mol. Biol. 2007, 103, 170-177. [CrossRef] [PubMed]

3. Gajecka, M. The effect of low-dose experimental zearalenone intoxication on the immunoexpression of estrogen receptors in the ovaries of pre-pubertal bitches. Pol. J. Vet. Sci. 2012, 15, 685-691. [CrossRef] [PubMed]

4. Benzoni, E.; Minervini, F.; Giannoccaro, A.; Fornelli, F.; Vigo, D.; Visconti, A. Influence of in vitro exposure to mycotoxin zearalenone and its derivatives on swine sperm quality. Reprod. Toxicol. 2008, 25, 461-467. [CrossRef] [PubMed]

5. Kuiper, G.G.J.M.; Lemmen, J.G.; Carlsson, B.; Corton, J.C.; Safe, S.H.; van der Saag, P.T.; van der Burg, B.; Gustafsson, J.A. Interaction of estrogenic chemicals and phytoestrogens with estrogen receptor $\beta$. Endocrinology 1998, 139, 4252-4263. [CrossRef]

6. Aiko, V.; Mehta, A. Occurrence, detection and detoxification of mycotoxins. Toxicol. Appl. Pharm. 2015, 50, 943-954. [CrossRef] [PubMed] 
7. Kosicki, R.; Blajet-Kosicka, A.; Grajewski, J.; Twaruzek, M. Multiannual mycotoxin survey in feed materials and feedstuffs. Anim. Feed Sci. Technol. 2016, 215, 165-180. [CrossRef]

8. Phuong, N.H.; Thieu, N.Q.; Ogle, B.; Pettersson, H. Aflatoxins, fumonisins and zearalenone contamination of maize in the southeastern and central highlands provinces of Vietnam. Agriculture 2015, 5, 1195-1203. [CrossRef]

9. Oliveiraa, M.S.; Rochaa, A.; Sulyok, M.; Krskab, R.; Mallmann, C.A. Natural mycotoxin contamination of maize (Zea mays L.) in the south region of Brazil. Food Control 2017, 73, 127-132. [CrossRef]

10. Lee, H.J.; Ryu, D. Worldwide occurrence of mycotoxins in cereals and cereal-derived food products: Public health perspectives of their co-occurrence. J. Agric. Food Chem. 2017, 65, 7034-7051. [CrossRef]

11. FAO. Worldwide Regulations for Mycotoxins in Food and Feed in 2003; FAO Food and Nutrition Paper No. 81; Food and Agriculture Organization of the United Nations: Rome, Italy, 2004.

12. Zinedine, A.; Soriano, J.M.; Molto, J.C.; Manes, J. Review on the toxicity, occurrence, metabolism, detoxification, regulations and intake of zearalenone: An oestrogenic mycotoxin. Food Chem. Toxicol. 2007, 45, 1-18. [CrossRef] [PubMed]

13. Bordini, J.G.; Borsato, D.; Oliveira, A.S.; Ono, M.A.; Zaninelli, T.H.; Hirooka, E.Y.; Ono, E.Y.S. In vitro zearalenone adsorption by a mixture of organic and inorganic adsorbents: Application of the Box Behnken approach. World Mycotoxin J. 2015, 8, 291-299. [CrossRef]

14. Markovic, M.; Dakovic, A.; Rottinghaus, G.E.; Kragovic, M.; Petkovic, A.; Krajisnik, D.; Milic, J.; Mercurio, M.; de Gennaro, B. Adsorption of the mycotoxin zearalenone by clinoptilolite and phillipsite zeolites treated with cetylpyridinium surfactant. Colloid Surf. B 2017, 151, 324-332. [CrossRef] [PubMed]

15. Wang, L.; Wang, Y.; Shao, H.L.; Luo, X.H.; Wang, R.; Li, Y.F.; Li, Y.N.; Luo, Y.P.; Zhang, D.J.; Chen, Z.X. In vivo toxicity assessment of deoxynivalenol-contaminated wheat after ozone degradation. Food Addit. Contam. A 2017, 34, 103-112. [CrossRef] [PubMed]

16. Yu, Y.S.; Qiu, L.P.; Wu, H.; Tang, Y.Q.; Yu, Y.G.; Li, X.F.; Liu, D.M. Degradation of zearalenone by the extracellular extracts of Acinetobacter sp. SM04 liquid cultures. Mycotoxin Biodegr. 2011, 22, 613-622. [CrossRef] [PubMed]

17. Kriszt, R.; Krifaton, C.; Szoboszlay, S.; Cserhati, M.; Kriszt, B.; Kukolya, J.; Czeh, A.; Feher-Toth, S.; Torok, L.; Szoke, Z.; et al. A new zearalenone mycotoxin biodegradation strategy using non-pathogenic Rhodococcus pyridinivorans K408 strain. PLoS ONE 2012, 7, e43608. [CrossRef] [PubMed]

18. Tang, Y.Q.; Xiao, J.M.; Chen, Y.; Yu, Y.G.; Xiao, X.L.; Yu, Y.S.; Wu, H. Secretory expression and characterization of a novel peroxiredoxin for zearalenone detoxification in Saccharomyces cerevisiae. Microbiol. Res. 2013, 168, 6-11. [CrossRef]

19. Lei, Y.P.; Zhao, L.H.; Ma, Q.G.; Zhang, J.Y.; Zhou, T.; Gao, C.Q.; Ji, C. Degradation of zearalenone in swine feed and feed ingredients by Bacillus subtilis ANSB01G. World Mycotoxin J. 2014, 7, 143-151. [CrossRef]

20. Zhao, L.; Jin, H.T.; Lan, J.; Zhang, R.Y.; Ren, H.B.; Zhang, X.B.; Yu, G.P. Detoxification of zearalenone by three strains of Lactobacillus plantarum from fermented food in vitro. Food Control 2015, 54, 158-164. [CrossRef]

21. Guo, J.; Zhang, L.S.; Wang, Y.M.; Yan, C.H.; Huang, W.P.; Wu, J.; Yuan, H.T.; Lin, B.W.; Shen, J.L.; Peng, S.Q. Study of embryo toxicity of Fusarium mycotoxin butenolide using a whole rat embryo culture model. Toxicol. In Vitro 2011, 25, 1727-1732. [CrossRef]

22. Wang, M.; Yin, L.; Hu, H.; Selvaraj, J.N.; Zhou, Y.; Zhang, G. Expression, functional analysis and mutation of a novel neutral zearalenone-degrading enzyme. Int. J. Biol. Macromol. 2018, 118, 1284-1292. [CrossRef] [PubMed]

23. Pereyra, C.M.; Cavaglieri, L.R.; Chiacchiera, S.M.; Dalcero, A. The corn influence on the adsorption levels of aflatoxin B1 and zearalenone by yeast cell wall. J. Appl. Microbiol. 2013, 114, 655-662. [CrossRef] [PubMed]

24. Yu, Y.; Wu, H.; Tang, Y.; Qiu, L. Cloning, expression of a peroxiredoxin gene from Acinetobacter sp. SM04 and characterization of its recombinant protein for zearalenone detoxification. Microbiol. Res. 2012, 167, 121-126. [CrossRef] [PubMed]

25. Zhang, H.; Dong, M.; Yang, Q.; Apaliya, M.T.; Li, J.; Zhang, X. Biodegradation of zearalenone by Saccharomyces cerevisiae: Possible involvement of ZEN responsive proteins of the yeast. J. Proteom. 2016, 143, 416-423. [CrossRef]

26. Cho, K.J.; Kang, J.S.; Cho, W.T.; Lee, C.H.; Ha, J.K.; Bin, S.K. In vitro degradation of zearalenone by Bacillus subtilis. Biotechnol. Lett. 2010, 32, 1921-1924. [CrossRef] 
27. El-Sharkawy, S.; Abul-Hajj, Y.J. Microbial cleavage of zearalenone. Xenobiotica 1988, 18, 365-371. [CrossRef] [PubMed]

28. Lei, Y.P. Mechanism of Degrading ZEA by ANSB01G Strain and Its Application Effect in Animal Production. Ph.D. Thesis, China Agricultural University, Beijing, China, 2014.

29. Brodehl, A.; Moller, A.; Kunte, H.J.; Koch, M.; Maul, R. Biotransformation of the mycotoxin zearalenone by fungi of the genera Rhizopus and Aspergillus. FEMS Micobiol. Lett. 2014, 359, 124-130. [CrossRef] [PubMed]

30. Tran, S.T.; Smith, T.K. Conjugation of deoxynivalenol by Alternaria alternate (54028 NRRL), Rhizopusmicrosporus var. rhizopodiformis (54029 NRRL) and Aspergillus oryzae (5509 NRRL). Mycotoxin Res. 2014, 30, 47-53. [CrossRef] [PubMed]

31. Zuo, R.Y.; Chang, J.; Yin, Q.Q.; Wang, P.; Yang, Y.R.; Wang, X.; Wang, G.Q.; Zheng, Q.H. Effect of the combined probiotics with aflatoxin B1-degrading enzyme on aflatoxin detoxification, broiler production performance and hepatic enzyme gene expression. Food Chem. Toxicol. 2013, 59, 470-475. [CrossRef]

32. Jiang, S.; Yang, Z.; Yang, W.; Gao, J.; Liu, F.; Chen, C.; Chi, F. Physiopathological effects of zearalenone in post-weaning female piglets with or without montmorillonite clay adsorbent. Livest. Sci. 2010, 131, 130-136. [CrossRef]

33. Oliver, W.T.; Miles, J.R.; Diaz, D.E.; Dibner, J.J.; Rottinghaus, G.E.; Harrell, R.J. Zearalenone enhances reproductive tract development, but does not alter skeletal muscle signaling in prepubertal gilts. Anim. Feed Sci. Technol. 2012, 174, 79-85. [CrossRef]

34. Brousseau, J.P.; Talbot, G.; Beaudoin, F.; Lauzon, K.; Roy, D.; Lessard, M. Effects of probiotics Pediococcus acidilactici strain MA18/5M and Saccharomyces cerevisiae subsp. boulardii strain SB-CNCM I-1079 on fecal and intestinal microbiota of nursing and weanling piglets. J. Anim. Sci. 2015, 93, 5313-5326. [CrossRef] [PubMed]

35. Wang, D.F.; Zhou, H.L.; Hou, G.Y.; Qi, D.S.; Zhang, N.Y. Soybean isoflavone reduces the residue of zearalenone in the muscle and liver of prepubertal gilts. Animal 2013, 7, 699-703. [CrossRef] [PubMed]

36. Gajecki, M. Evaluation of selected serum biochemical and haematological parameters in gilts exposed to 100 ppb of zearalenone. Pol. J. Vet. Sci. 2015, 18, 865-872.

37. Marin, D.E.; Pistol, G.C.; Neagoe, I.V.; Calin, L.; Taranu, I. Effects of zearalenone on oxidative stress and inflammation in weanling piglets. Food Chem. Toxicol. 2013, 58, 401-408. [CrossRef] [PubMed]

38. Zhao, L.H.; Lei, Y.P.; Bao, Y.H.; Jia, R.; Ma, Q.G.; Zhang, J.Y.; Chen, J.; Ji, C. Ameliorative effects of Bacillus subtilis ANSB01G on zearalenone toxicosis in pre-pubertal female gilts. Food Addit. Contam. A 2015, 34, 617-625. [CrossRef] [PubMed]

39. Niu, Q.S. Effect of Fusarium Toxins on Hematological Values, Development of Reproductive Organs, and Expression of Estrogen Receptor Genes in Post-Weaning Gilts. Ph.D. Thesis, Shandong Agricultural University, Taian, China, 2015.

40. Liu, X.L.; Wu, R.Y.; Sun, X.F.; Cheng, S.F.; Zhang, R.Q.; Zhang, T.Y.; Zhang, X.F.; Zhao, Y.; Shen, W.; Li, L. Mycotoxin zearalenone exposure impairs genomic stability of swine follicular granulosa cells in vitro. Int. J. Biol. Sci. 2018, 14, 294-305. [CrossRef]

41. Muthulakshmi, S.; Hamideh, P.F.; Habibi, H.R.; Maharajan, K.; Kadirvelu, K.; Mudili, V. Mycotoxin zearalenone induced gonadal impairment and altered gene expression in the hypothalamic-pituitary-gonadal axis of adult female zebrafish (Danio rerio). J. Appl. Toxicol. 2018, 38, 1388-1397. [CrossRef]

42. Cao, H.; Liu, D.L.; Mo, X.M.; Xie, C.F.; Yao, D.L. A fungal enzyme with the ability of aflatoxin B1 conversion: Purification and ESI-MS/MS identification. Microbiol. Res. 2011, 166, 475-483. [CrossRef]

43. Yin, Q.Q.; Fan, G.G.; Chang, J.; Zuo, R.Y.; Zheng, Q.H. Effect of the combined probiotics on inhibiting pathogenic Escherichia coli proliferation. Adv. Mater. Res. 2012, 343, 802-808.

44. Huang, W.W.; Chang, J.; Wang, P.; Liu, C.Q.; Yin, Q.Q.; Zhu, Q.; Lu, F.S.; Gao, T.Z. Effect of the combined compound probiotics with mycotoxin-degradation enzyme on detoxifying aflatoxin B1 and zearalenone. J. Toxicol. Sci. 2018, 43, 377-385. [CrossRef] [PubMed]

45. National Research Council (NRC). Nutrient Requirements of Swine, 11th rev. ed.; National Academic Press: Washington, DC, USA, 2012.

46. Jurgens, M.H. Animal Feeding and Nutrition, 8th ed.; Kendall/Hunt Publishing Company: Dubuque, IA, USA, 1997.

47. Livak, K.J.; Schmittgen, T.D. Analysis of relative gene expression data using real-time quantitative PCR and the $2-\Delta \Delta$ CT method. Methods 2001, 25, 402-408. [CrossRef] [PubMed] 
48. Maibach, R.C.; Dutly, F.; Altwegg, M. Detection of Tropheryma whipplei DNA in feces by PCR using a target capture method. J. Clin. Microbiol. 2002, 40, 2466-2471. [CrossRef] [PubMed]

49. Liu, C.Q.; Zhu, Q.; Chang, J.; Yin, Q.Q.; Song, A.D.; Li, Z.T.; Wang, E.Z.; Lu, F.S. Effects of Lactobacillus casei and Enterococcus faecalis on growth performance, immune function and gut microbiota of suckling piglets. Arch. Anim. Nutr. 2017, 71, 120-133. [CrossRef] [PubMed]

50. Konstantinov, S.R.; Zhu, W.Y.; Williams, B.A.; Tamminga, S.; de Vos, W.M.; Akkermans, A.D.L. Effect of fermentable carbohydrates on piglet faecal bacterial communities as revealed by denaturing gradient gel electrophoresis analysis of 16 S ribosomal DNA. FEMS Microbiol. Ecol. 2003, 43, 225-235. [CrossRef]

(C) 2019 by the authors. Licensee MDPI, Basel, Switzerland. This article is an open access article distributed under the terms and conditions of the Creative Commons Attribution (CC BY) license (http://creativecommons.org/licenses/by/4.0/). 